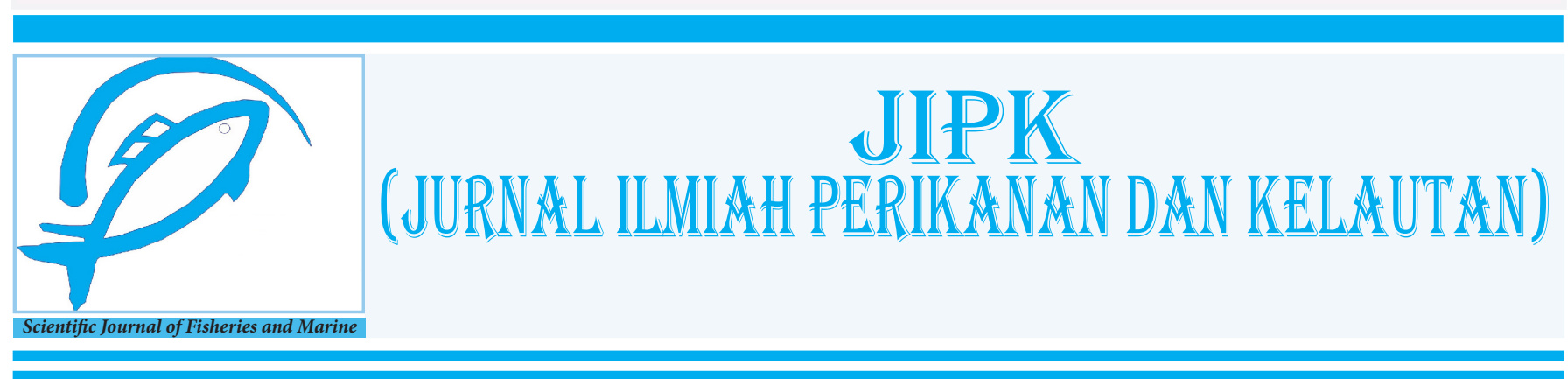

Research Article

\title{
Assessing Price Behavior of Tuna (Thunnus spp.) in Indonesia
}

\author{
Ketut Sukiyono* iD, Putri Suci Asriani, Redy Badrudin, Nola Windirah, Rahmi Yuristia, and \\ Musriyadi Nabiu
}

Department of Agricultural Socio-Economics, Faculty of Agricultural, University of Bengkulu. Indonesia

\section{OPEN O ACCESS}

\section{ARTICLE INFO}

Received: October 22, 2021

Accepted: December 10, 2021

Published: December 23, 2021

*) Corresponding author:

E-mail: ksukiyono@unib.ac.id

Keywords:

Tuna

Price Behavior

Trend, Variability

Seasonality

Integration

This is an open access article under the CC BY-NC-SA license (https://creativecommons.org/ licenses/by-nc-sa/4.0/)

\section{Abstract}

Prices of agricultural and fisheries products have always been a concern not only by producers and consumers but also by the government in designing policies to control and stabilize these prices to protect the poor. Therefore, a study of price behavior is crucial to be scrutinized more deeply and comprehensively. This research is aimed at examining and analyzing tuna (Thunnus spp.) price behavior in terms of their seasonal, trend, variability, and instability behavior as well as their market integration. For this purpose, monthly data of tuna prices from 2011:1 to 2019:12 in five tuna production centers (provinces) in Indonesia, including North Sulawesi, West Papua, Aceh, North Maluku, and Bali, at the national level were applied. It was found that tuna prices have a positive trend and are statistically significant, excluding in West Papua. The study also found that price variability and instability were insignificant during observations. The study also concluded that the tuna price in every single province in Indonesia is formed independently.

Cite this as: Sukiyono, K., Putri Suci Asriani, Redy Badrudin, Nola Windirah, Rahmi Yuristia, and Musriyadi Nabiu (2022). Assessing Price Behavior of Tuna (Thunnus spp.) in Indonesia. Jurnal Ilmiah Perikanan dan Kelautan, 14(1):118-129. http://doi. org/10.20473/jipk.v14i1.30100 


\section{Introduction}

The price fluctuation of agricultural products always triggers government intervention in agricultural markets, on the pretext of protecting the poor. This is widely recognized by poor households in developing countries, especially in rural areas. Many studies have also concluded the significant impact of price volatility on farmer welfare. Research by Makbul et al. (2019), for example, concluded that the price of rice shows a significant effect on the welfare of farmers in the short term, but not in the long term. Research by Sukiyono et al. (2017) also concluded that the volatility of palm oil prices influences the vulnerability of oil palm farmers. Meanwhile, a study by Nakelse et al. (2018) has also concluded that a rise in prices has been translated into an increase in household welfare in Burkina Faso. These findings indicate the significance of price information for farmers, including consumers. Price is often used as a signal for farmers or producers to produce and to market. Therefore, assessing the price behavior of agricultural products is very important not only for farmers, fishermen, and producers but also for policymakers in formulating price policies.

Formal analysis of price behavior has been widely studied, both for agricultural and non-agricultural product prices. One frequent study on price behavior is price volatility. For agricultural product, price volatility is a significant feature (Camara, 2013; Mustapha and Richard, 2013; Kaminski et al., 2016). In term of price volatility of agricultural products, several studies have been conducted among others by Miftahuljanah et al. (2020) on curly red chili price, and Singvejsakul et al. (2021) on cassava chips. Another important price behavior analysis is price rigidity. Price rigidity can simply be defined as a situation where the price of a good does not change rapidly when the supply and demand curve equilibrium changes. Price rigidity, also known as price stickiness or sticky prices, is often caused by buyer or seller failures to adapt to new conditions in the market when the market-clearing price occurs (see Levy (2007); Singh and $\mathrm{Ru}$ (2019) for discussion). Another topic of price behavior analysis is the variation and dispersion of prices. Price variation refers to the difference in prices that consumers have to pay for the same product at different places, while price dispersion refers to the behavior of sellers who offer the same goods at different prices. Hassanzoy et al. (2016) stated that price variation has been a major source of concern for economic policy planning due to its impact on economic activity. These two topics have been widely studied, among others are Chatterjee and Kapur (2016); Kumar and Sharma (2006); Baye et al. (2004); and Lach (2002). However, there is also an analysis of price behavior which is intended to study trends, fluctuations, and volatility of prices, and so forth. Furthermore, according to Hoffmann (1998), understanding seasonal variation in agricultural prices is critical for directing farm producer and trader decisions, as well as articulating government agricultural policies. Thus, price formation analysis in the agricultural market is critical to guiding producers in deciding how much to produce and to whom to sell in order to maximize profits. Singh et al. (2017); Devi et al. (2016). Neupane and Calkins (2013), and Sukiyono and Kaban (2007) are some examples of research that are concerned with analyzing price behavior.

The literature study above informed that various models can be used in assessing price behavior. The use of a model to analyze prices depends on the purpose of the research being carried out and of course the data availability. So far, studies of price behavior research have been very difficult to find, if not none, studies that have focused on the price behavior of capture fisheries, such as tuna. Therefore, research that focuses on the study of tuna fish behavior will enrich the capture fisheries scientific literatures from the economic studies and models views. In addition, the contribution of the marine fisheries sector to a country's economy is very significant, including in Indonesia. The behavior of fishery product prices will certainly have quite an important impact on the welfare of fishermen, business in the fisheries sector and the country's economy.

Aquaculture and catch fishery are amongst the primary industries in Indonesia. At least, this sector has three main roles, namely a source of economic growth, a source of food, especially animal protein, and a provider of employment, as revealed in studies conducted by Purnomo (2012); Triarso (2012); Rizal et al. (2018); and Sanger et al. (2019). In addition, catch fisheries in Indonesia have a significant role in world catch fisheries production as reported by FAO (2018). FAO informed that Indonesia has contributed to world catch production by $7.19 \%$ (6.54 million tonnes) in 2016 or one level below China's 17.56 million tonnes (19.29\%). One important catch fisheries product for the Indonesian economy is tuna (Thunnus spp.). In 2011, tuna catch contributed amounted to US $\$ 498,591,000$ or $14 \%$ of the total export value of Indonesian fisheries. According to Yusuf et al. (2017), this figure is far from the potential for tuna which is estimated to reach 1.2 million tons per year, and with an export value of more than US \$ 3.5 billion. The quantity of tuna exported is not only considering production and consumption, price is often the 
main consideration. In many studies, domestic prices and also export prices affect the quantity or export of agricultural products, such as research by Maygirtasari et al. (2015) for CPO; and Widayanti et al. (2009) for Cofee. Therefore, studying tuna fish price behavior is very important to be able to improve the performance of Indonesian tuna exports in the future and this research addressed this task.

Agricultural and fishery product prices are generally volatile over time, among others due to the influence of climate, supply, demand, and seasonality production. These factors make a difficulty in planning and adjusting between production and market, forcing producers to be more cautious with price fluctuations and how the price behaves.

\section{Materials and Methods}

\subsection{Data Sources}

This research data is the monthly price data for tuna fish 2011: 1 - 2019: 12 in five tuna production centers (provinces) in Indonesia and prices at the national level. The five tuna production centers include North Sulawesi, West Papua, Aceh, North Maluku, and Bali. This data is compiled from the publication of the Indonesian Central Bureau of Statistics.

The monthly tuna prices exhibit fluctuation during observation and seem to have a positive trend with exception of West Papua (Figure 1). In this province, the domestic tuna prices do not exhibit a trend even though

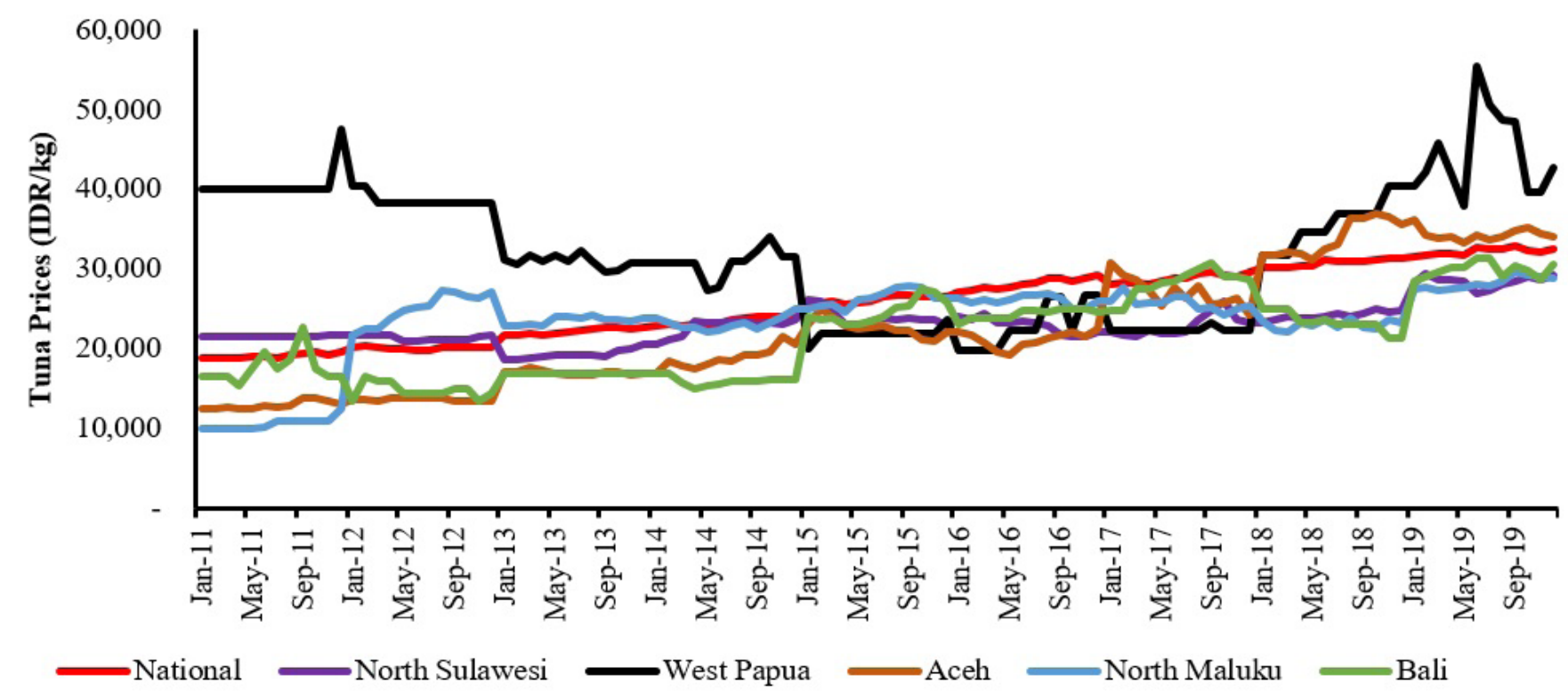

Figure 1. Monthly Tuna Price Series in Indonesia

Source: Indonesian Central Bureau of Statistics (various publication)

Table 1. Descriptive Statistics of Tuna Price in Indonesia, $2011-2019$ (IDR/kg)

\begin{tabular}{lcccc}
\hline \multicolumn{1}{c}{ Province } & Mean & St. Deviation & Minimum & Maximum \\
\hline North Sulawesi & $23,076.00$ & $2,506.10$ & $18,693.00$ & $29,487.00$ \\
North Maluku & $23,540.00$ & $4,939.50$ & $10,050.00$ & $29,687.00$ \\
West Papua & $32,041.00$ & $8,317.70$ & $19,878.00$ & $55,402.00$ \\
Bali & $21,768.00$ & $5,383.30$ & $13,500.00$ & $31,341.00$ \\
Aceh & $22,420.00$ & $7,608.10$ & $12,474.00$ & $36,884.00$ \\
National & $25,675.00$ & $4,477.40$ & $18,788.00$ & $32,834.00$ \\
\hline
\end{tabular}


they fluctuate which is initiated with a downward trend and followed by an upward trend. Again, West Papua province experiences the highest tuna prices at mean and standard deviation (Table 1). A high standard deviation indicates that the tuna prices are spread out over a wider range of observations and are clustered around the tuna price mean.

\subsection{Analytical Method}

\subsubsection{Estimation of seasonal price behavior}

Many approaches can be applied to measure the seasonal index of agricultural product prices, including the Seasonal Variation Index (SVI) proposed by Arias et al. (2009). SVI is estimated by dividing the monthly arithmetic means $\left(\mathrm{Y}_{\mathrm{t}}\right)$ in each period by the general average of the series values in the period (CMA). In simple terms, SVI is formulated as follows:

$$
S V I=\frac{Y_{t}}{C M A}
$$

Furthermore, the estimated lower and upper confidence limits (LCR and HCL) for the period are calculated by the following equation (Arias et al., 2009):

$$
L C R \geq \frac{L}{C M A} \quad \text { (2), and }
$$$$
H C L \leq \frac{H}{C M A}
$$

Where $\mathrm{L}$ is the lowest monthly series value each year, and $\mathrm{H}$ denotes the highest monthly series value each year.

\subsubsection{Estimation of price instability}

Price variability is often measured by the coefficient of variation $(\mathrm{CV} \%)$ as an indicator of price instability. The CV measures the variability of a population relative to its mean and standard deviation, and is formulated as follows:

$$
C V=\frac{S D}{\bar{P}} \times 100 \%
$$

where SD denotes standard deviation and denotes price means. Various studies applied this approach to measure price instability, among others by Sharma and Burark (2015), Khajuria et al. (2008), and Kumar et al. (2006). However, the use of CV as a measure of price instability is often overestimated due to its trend component. For this reason, the tuna price instability, indicated by the Price Instability Index (PII), is estimated with the following formulae as suggested by Cuddy and Della (1978) and applied among others by Pandhit et al. (2012), Goyal (2008), and Thumar et al. (2006):

$$
P I I=C V \times \sqrt{\left(1-R^{2}\right)}
$$

where $\mathrm{R}^{2}$ represents coefficient determination.

Price behavior analysis in this study is also equipped by examining the degree of the price disparity between the highest and lowest prices.

\subsubsection{Evaluation price linkages among main ports}

The five tuna landing ports which are the object of research are spread from the western end to the eastern end of Indonesia. The question that needs to be answered is whether there is a price correlation among these ports which can be considered as spatially separate markets. To examine the price correlation between ports, a simple bivariate statistic model for correlation analysis is employed as follows:

$$
r=\frac{\sum P_{i} P_{j}-\frac{\left(\sum P_{i}\right)\left(\sum P_{j}\right)}{N}}{\sqrt{\left(\sum P_{i}^{2}-\frac{\left(\sum P_{i}\right)^{2}}{N}\right)\left(\sum P_{j}^{2}-\frac{\left(\sum P_{j}\right)^{2}}{N}\right)}}
$$

Testing the significance of the correlation between markets used the t-test as follows:

$$
t=\frac{r \sqrt{N-2}}{\sqrt{1-r^{2}}}
$$

This approach is also proposed by Singh et al. (2017) and Rana et al. (2003). 


\section{Results and Discussion}

\subsection{Tuna Price Trend}

The trend coefficients of national and all ports, with exception of West Papua, showed a positive sign with a linear pattern (Table 2). These findings indicated an increase in the prices of tuna during the observations. This occurrence may be due to demand growth for Tuna, especially demand for Tuna export whether in the form of fresh tuna or processed products. As reported by Tridge Market Intelligent (TMI) (2021), in 2020, the Indonesian Tuna exports value was $\$ 192.1 \mathrm{M}$, increased by $111.65 \%$ during the last 5 years.

All trend coefficients have a positive sign and are significantly different from Zero, excluding West Papua (Table 2). The trend coefficient in West Papua has a negative sign and is insignificant at all levels of significance. In this province, the coefficient determination $\left(\mathrm{R}^{2}\right)$ of the trend model was the lowest, i.e., $0.73 \%$. Looking at the $\mathrm{F}$ test, it is found that the $\mathrm{F}$ ratio is less than its level significance. This indicates that the trend model is unable to apply in explaining the variation of tuna price in conjunction with the trend variable. This finding is reasonable in which West Papua tuna prices unlikely exhibited a linear trend (Figure 1). This result differs from others ports as well at the national level. At the national level, the trend variable is significant at $90 \%$, however, its $\mathrm{R}^{2}$ value is $98.71 \%$. These findings inform that the trend forecasting is sufficient to explain the tuna price behavior in Indonesia. This conclusion is also supported by the $\mathrm{F}$ ratio by which is significantly different from zero at any level of significance.
Different results are shown at landing ports, even though statistically all trend models have positive signs and significance at any level of significance, they have a different level of goodness of fit $\left(\mathrm{R}^{2}\right)$. In a linear regression model, the coefficient of determination $\left(\mathrm{R}^{2}\right)$ is used to determine the goodness of fit (Cheng et al., 2014). In addition, an $\mathrm{R}^{2}$ value closes to $1(100 \%)$ implies that there is an almost perfect relationship between the model and the data, as in Aceh. However, it should be noted that there are no commonly accepted standards for what constitutes a good $\mathrm{R}^{2}$ value.

The positive trend coefficient in the four provinces and Indonesia illustrate that the trend of tuna prices increases continuously during the observation with exception of West Papua. This positive trend in tuna prices informs that there will be a continuous increase in the future. Many factors are suspected to be the cause of this phenomenon, one of which is the existence of Indonesian government policies related to capture fisheries management. One of the government policies related to capture fisheries management is the Minister of Maritime Affairs and Fisheries Regulation number 57/PERMEN-KP/2014, which is the Indonesian government's policy related to the prohibition of illegal fishing and transshipment (KKP, 2014). This policy will have an impact on the tuna supply in the world, including Indonesia which in turn having an impact on the tuna price accompanied by an increase in world demand, as indicated by the increasing value of Indonesian tuna exports. This policy of the Indonesian government has placed Indonesia as the largest tuna exporter as reported by TMI (2021).

Table 2. Linear Trend Model for Tuna price at Five Provinces in Indonesia

\begin{tabular}{rlrccc}
\hline No & Province & Trend coefficient & $\mathbf{t}_{\text {ratio }}$ & $\mathbf{F}_{\text {ratio. }}$ & \multicolumn{1}{c}{$\mathbf{R}^{2}$} \\
\hline 1 & North Sulawesi & 59.742 & $11.560^{* * *}$ & $133.536^{* * * *}$ & 55.75 \\
2 & North Maluku & 99.730 & $8.404^{* * *}$ & $70.635^{* * *}$ & 39.99 \\
3 & West Papua & -22.680 & -0.8825 & 0.779 & 0.73 \\
4 & Bali & 145.430 & $16.340^{* * *}$ & $267.109^{* * *}$ & 71.59 \\
5 & Aceh & 231.530 & $32.450^{* * *}$ & $1052.784^{* * *}$ & 90.85 \\
\hline & National & 142.030 & $1.578^{*}$ & $8100.000^{* * *}$ & 98.71 \\
\hline
\end{tabular}

Note: $* * *$ significance at $99 \% ; * *$ significance at $95 \%$; and $*$ significance at $90 \%$

$\mathrm{t}_{(0.01,100)}: 2.234 ; \mathrm{t}_{(0.05,100)}: 1.660$; and $\mathrm{t}_{(0.10,100)}: 1.290 \mathrm{~F}_{(0.05 ; 1,100)}: 3.94$ 


\subsection{Seasonal Behavior of Tuna Price}

As discussed in research methods, the seasonal pattern of tuna prices in Indonesia was analyzed by the construction of a seasonal variation index as suggested by Arias et al. (2009). Generally, the seasonal variation index (SVI), as well as Lower and Upper Confidence Limit (LCL and HCL) varied among different months and main ports however, the highest SVI often occurs from July to December (Table 3 and Figure 2). to reduce the average SVI, about $99 \%$. This relatively very small decline in the price of tuna over a long period (6 months) is certainly very beneficial for tuna producers or fishermen. That is, they do not encounter the risk of a sharp decline in prices.

The high SVIs, more than 100.0, occurred from July to December at the National level. At the national level, the highest SVI was 102.17. This value indicates that tuna price on national level for the month of December

Table 3. Seasonal Indices of Tuna Price at Different Province and National Level

\begin{tabular}{|c|c|c|c|c|c|c|c|c|c|c|c|c|c|c|c|c|c|c|}
\hline \multirow{2}{*}{$(\%)$} & \multicolumn{3}{|c|}{ North Sulawesi } & \multicolumn{3}{|c|}{ North Maluku } & \multicolumn{3}{|c|}{ West Papua } & \multicolumn{3}{|c|}{ Bali } & \multicolumn{3}{|c|}{ Aceh } & \multicolumn{3}{|c|}{ National } \\
\hline & SVI & LCR & HCL & SVI & LCR & HCL & SVI & LCR & HCL & SVI & LCR & HCL & SVI & LCR & HCL & SVI & LCR & HCL \\
\hline Jan & 99.42 & 81.01 & 122.64 & 97.53 & 42.69 & 116.64 & 95.96 & 62.04 & 126.28 & 96.75 & 62.02 & 131.28 & 101.24 & 55.64 & 161.11 & 97.90 & 73.54 & 123.26 \\
\hline Feb & 99.96 & 81.01 & 127.78 & 98.05 & 42.69 & 117.96 & 96.99 & 62.04 & 131.33 & 98.72 & 75.80 & 133.87 & 101.10 & 56.07 & 153.22 & 98.39 & 73.27 & 123.82 \\
\hline March & 99.77 & 81.57 & 124.22 & 96.82 & 42.69 & 116.00 & 97.92 & 62.04 & 142.87 & 99.56 & 72.08 & 136.12 & 99.92 & 56.91 & 151.40 & 98.56 & 73.18 & 124.44 \\
\hline April & 99.76 & 82.30 & 124.53 & 97.44 & 42.69 & 116.60 & 97.37 & 62.04 & 130.87 & 97.64 & 68.80 & 138.83 & 97.68 & 56.11 & 152.13 & 98.34 & 73.24 & 124.30 \\
\hline May & 99.05 & 83.71 & 123.61 & 98.93 & 42.69 & 117.65 & 95.84 & 68.38 & 124.84 & 98.56 & 66.61 & 138.83 & 95.74 & 56.11 & 148.65 & 98.57 & 73.82 & 123.36 \\
\hline June & 98.72 & 83.71 & 116.40 & 100.64 & 43.32 & 119.20 & 101.80 & 68.38 & 172.91 & 101.26 & 66.61 & 143.98 & 99.09 & 57.75 & 152.72 & 99.77 & 73.85 & 127.58 \\
\hline July & 99.46 & 83.71 & 118.55 & 101.03 & 46.71 & 118.59 & 102.58 & 68.38 & 158.08 & 100.90 & 66.61 & 143.98 & 98.41 & 56.95 & 150.61 & 100.48 & 73.74 & 126.81 \\
\hline Augt & 100.15 & 83.71 & 121.46 & 102.86 & 46.84 & 121.02 & 102.91 & 68.38 & 152.05 & 101.04 & 66.61 & 137.51 & 101.48 & 57.75 & 162.68 & 101.39 & 74.79 & 126.81 \\
\hline Sept & 100.38 & 82.85 & 123.62 & 102.04 & 46.84 & 126.11 & 103.12 & 68.38 & 151.47 & 104.78 & 68.91 & 141.81 & 101.35 & 60.42 & 162.28 & 101.79 & 75.48 & 127.88 \\
\hline Oct & 101.65 & 86.06 & 125.98 & 100.72 & 46.84 & 124.11 & 98.95 & 68.38 & 124.84 & 102.15 & 68.91 & 136.62 & 101.80 & 60.42 & 164.51 & 101.33 & 76.12 & 125.97 \\
\hline Nov & 100.48 & 87.01 & 124.41 & 101.02 & 46.84 & 123.05 & 101.17 & 68.38 & 126.28 & 99.11 & 62.02 & 133.76 & 101.70 & 60.12 & 162.95 & 101.32 & 75.24 & 125.46 \\
\hline Dec & 101.19 & 89.09 & 126.67 & 102.91 & 52.99 & 122.51 & 105.39 & 69.79 & 148.25 & 99.53 & 66.61 & 140.53 & 100.47 & 58.54 & 158.77 & 102.17 & 76.40 & 126.71 \\
\hline
\end{tabular}

Seasonal variation is another component of a time series that reflects frequencies of above-average and below-average activity throughout the year. In terms of tuna prices, the real price for some months could be higher than the average, as indicated by an index of greater than 100.0, while the price for other months was lower. From January to May, the SVI was less than 100; indicating that the tuna prices were below the average price during the observation with the exception in North Sulawesi and Aceh (Table 3). In these two regions, SVI of less than 100 occurred until July. The low price seasonal variation index is most likely due to the friendliness of the season or the weather for fishing as reported by Uktolseja et al. (1991), the peak of the fishing season for large pelagic fish occurs at the beginning of the year, especially between April, May and June. As a result, the relatively large amount of fish available has implications for the relatively stable price of fish, including the price of tuna. In general, the decline in prices below the average price is relatively small, which is around 1-2\%. This value is estimated by reducing the average value as compared to the annual average tuna price is $102.17 \%$. However, the highest SVI at the provincial level occurred differently. In Bali, for example, the highest SVI occurred in September, while in North Sulawesi the highest SVI was in October (Table 3). The SVI of 104.78 in September in Bali indicated that the average tuna price in September as compared to the annual average tuna prices in Bali was $104.78 \%$. One of the arguments that can explain this finding is that December is not fishing season, as Kekenusa et al. (2012) found for the skipjack tuna in North Sulawesi. Limited skipjack or tuna can cause high fish prices.

An SVI of more than 100 is particularly advantageous for tuna fishermen because high SVI also implies high tuna price. Of course, this is inversely proportional to consumers who prefer a low SVI as an indication of low tuna prices as well. This condition will certainly relate to the price risk faced by tuna producers. Theoretically, a low SVI should drive customers to consume more tuna, while on the other hand, a high SVI should 
cause consumers to consume less tuna. This seasonal price behavior is similar to the seasonal behavior of Tuna production, as was the case in Aceh. Nasution et al. (2019) found the results of forecasting the amount of tuna production landed at the Port of Aceh formed a seasonal pattern that tends to be the same as in previous years. This is what supports the relatively stable price of tuna in Aceh Port (Sidik et al. 2013).

In general, it can be concluded that almost all of the studied provinces have the same seasonal price behavior with relatively similar SVI values, ranging from $99 \%$ to $103 \%$ (Table 3 ). This means that there is a relatively small increase and decrease in prices. The seasonal index of the price of tuna at the port in the north Maluku region shows a relatively low price fluctuation. Research by Agus (2018) found that currently, it is quite difficult for fishermen to collect 1 ton of marine catch

North Sulawesi

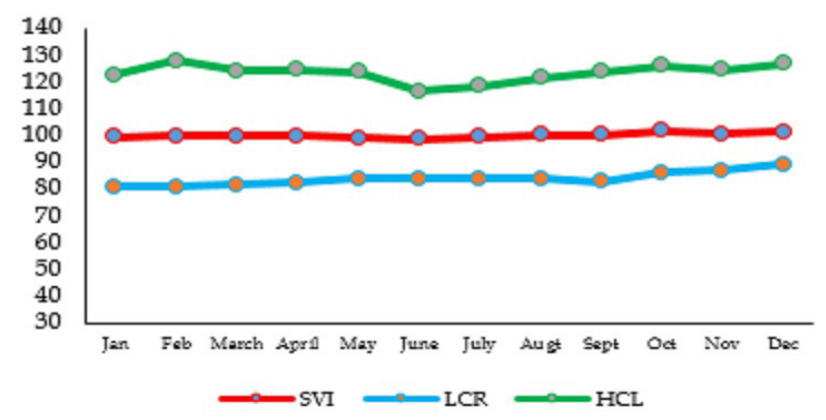

West Papua

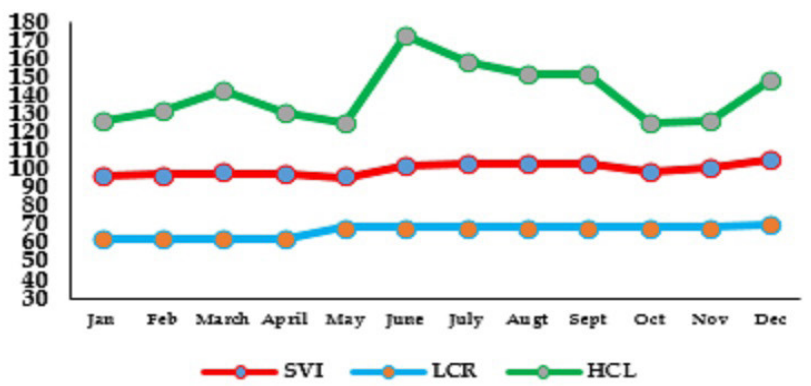

Aceh

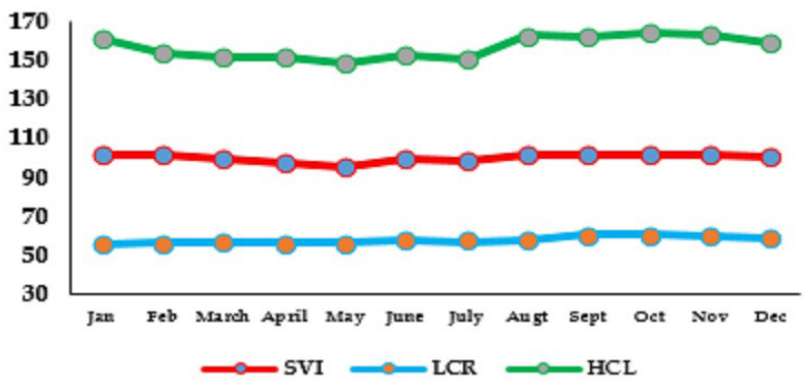

in a month in the Ternate Sea which results in reduced availability of tuna in North Maluku ports and this will ultimately affect the prevailing price movements. Meanwhile, the port areas of West Papua and Bali are ports that have significant price movements. The level of exploitation of tuna in Bali has been categorized as overfishing, where the exploitation rate value obtained exceeds the optimum utilization rate (Kurniawan et al., 2016). In addition, this finding will certainly be very easy for the government to intervene to prevent uncontrolled fluctuations in tuna prices to harm tuna fishermen and consumers.

\subsection{Tuna Price Variability and Instability}

The Tuna price variability in major provinces and at the national level is presented in (Table 5). The table shows that the instability indices (PII) in all landing
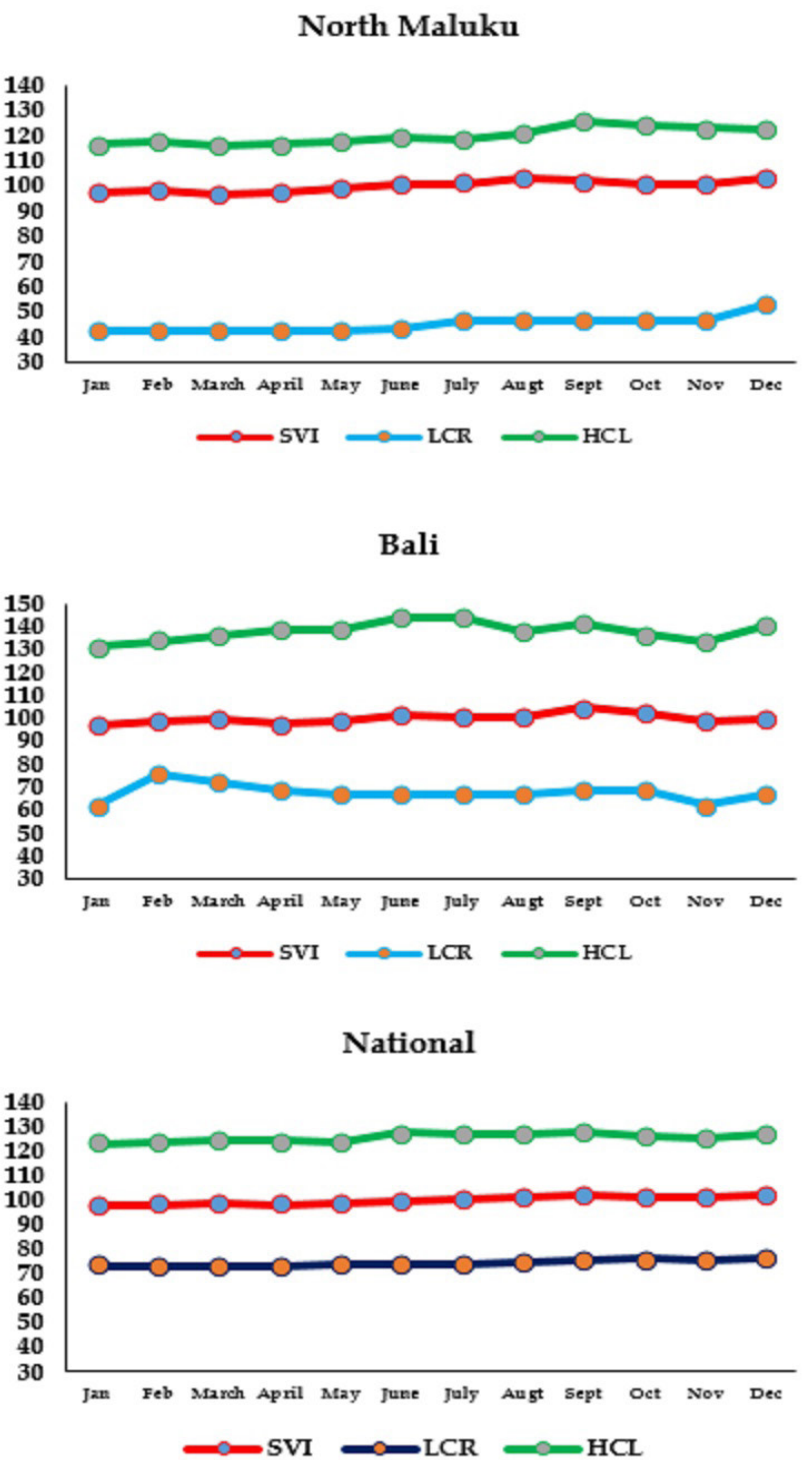

Figure 2. Seasonal variation Index (SVI), Lower and Upper Confidence Limit (LCL and HCL) of Tuna Prices in Indonesia 
ports (provinces) range from 7.22 to 25.86 while at the national level, the PII is 1.98. This table also informs that West Papua has experienced the highest price instability with the PII of 25.86. However, the price variability at this port is lower than in Aceh, which is indicated by the CV value of 25.96 which is lower than the Aceh CV value of 33.93. This finding reveals that even though Tuna price in West Papua is less stable, the monthly price variability is more evenly distributed. In contrary to Aceh, the price is more stable while monthly price distribution is uneven. There is no guarantee that if the monthly prices vary less the price will be stable. In the case of tuna prices in Indonesia, there is an inverse relationship between price variability and price instability. Further, this phenomenon occurs in all ports studied. This finding also proves that $\mathrm{CV}$ is difficult to describe the condition of price instability. The main reason is that $\mathrm{CV}$ frequently includes the trend component and so overestimates the extent of price instability. Although, many researchers, such as Khajuria et al. (2008), and Singh et al. (2017), have employed CV to measure price instability. What needs to be understood is that $\mathrm{CV}$ also implies the existence of risk. Nidausoleha (2007), for instance, explains that the $\mathrm{CV}$ portrays fluctuations, i.e., deviation from the mean, in which these fluctuations reveal risk. These risks, for example, are due to a lack of ability to determine the selling price. In addition, the occurrence of risks could be caused by the supply-demand imbalance for tuna.

Looking at price divergences, the difference between the highest and the lowest prices in percentage during the observation $(2011-2019)$, the lowest divergence occurs in North Sulawesi, i.e., 36.61\%. This indicates that monthly tuna prices in North Sulawesi tend to be stable and lower disparity as shown by the lowest CV and PII (Table 4). North Sulawesi is the province with the largest tuna production in Indonesia, contributing on average $18 \%$ to national production in $2018-2019$ (KKP, 2021). The dominance of tuna production could be the main factor in explaining less variability and steadiness of tuna price in this province. Overall, the price divergence ranges $36.61 \%-66.18 \%$ where tuna prices in Aceh have the highest divergence. However, this province has the second-lowest price instability index after North Sulawesi, i.e., 10.26.

The lowest prices occur in the months at the beginning of the year, while the highest prices are found in the months preceding the end of the year (Table 4). This incident is related to the fishing season in the peak fishing season generally ranges from the first transitional season (April, May, and June) to the beginning of the east season. The peak of the fishing season is characterized by the abundance of catches which causes the price of the fish caught to fall, on the other hand, when it is not the fishing season, prices tend to start creeping up.

The conclusion that can be drawn is that the tuna fishing industry does not have a relatively high price risk (Table 4). This conclusion is based on the relatively small CV values for each province. This conclusion is also shown by the relatively small value of the price instability index.

\subsection{Relation among Market Price}

The question of whether the price of tuna among landing ports is related to each other is answered by studying the price correlation between these ports. This correlation will also illustrate the integration of the tuna market between major ports in Indonesia. Market integration explains the relationship between two different markets, and it is considered to be integrated if the prices in the two markets are decided interdependently. It refers to a situation in which arbitrage drives prices in many markets to move together. This concept can also be used as a measure of marketing efficiency. The degree of market integration is measured by how closely prices in spatially disparate markets move together. As

Table 4. Tuna Price Variability and Instability among Main Ports in Indonesia, 2011 - 2019

\begin{tabular}{clcccll}
\hline No & Province & $\begin{array}{c}\text { Divergence } \\
(\mathbf{\%})\end{array}$ & CV & PII & Lowest (Month) & Highest (Month) \\
\hline 1 & North Sulawesi & 36.61 & 10.86 & 7.22 & February_2013 & February_2019 \\
2 & North Maluku & 66.15 & 20.98 & 16.26 & January_2011 & September_2019 \\
3 & West Papua & 64.12 & 25.96 & 25.86 & March_2016 & June_2019 \\
4 & Bali & 56.93 & 24.73 & 13.18 & November_2012 & July_2019 \\
5 & Aceh & 66.18 & 33.93 & 10.26 & January_2011 & October_2018 \\
6 & National & 42.78 & 17.44 & 1.98 & March_2011 & September_2019 \\
\hline
\end{tabular}


discussed in the research method, this study employs the correlation coefficient to examine the existence of market integration where the higher the correlation coefficient, the more integrated the two markets are.

The pairwise correlation coefficient among main ports ranges from $0.0544-0.5981$ (Table 5). This value informs that the price correlation among provinces does not exist. The relationship between these two markets is very weak and significant, as indicated by a low correlation value but a significant t-test value at least at the $90 \%$ significance level. This weak relationship also indicates the possibility that they have different markets or consumers for their products so that prices in each market do not affect each other. The formation of tuna prices in each market, in this case, the province, is independent and does not affect each other. as well as fishing grounds located below and above the equator allow Indonesian fishermen to carry out fishing activities regardless of the season. This condition may cause seasonal price behavior to tend to be invisible.

The study also found that there was no significant problem with price variability and instability. The low price instability index in all provinces and national levels indicated that price risk is seemingly low in Indonesia. The price variability exhibited during the 9 years observations $(2011$ - 2019) was also relatively low. This finding also informed that tuna price volatility was also low. Again, price risk was not a major obstacle for developing tuna industries in Indonesia. This also informed that the tuna industry in Indonesia is profitable and feasible to develop. The results of this study

Table 5. Pair-wise Correlation Coefficient between Main Ports in Indonesia, 2011 - 2019

\begin{tabular}{|c|c|c|c|c|c|}
\hline & North Sulawesi & North Maluku & West papua & Bali & Aceh \\
\hline \multirow{2}{*}{$\begin{array}{l}\text { North } \\
\text { Sulawesi }\end{array}$} & \multirow{2}{*}{1} & & & & \\
\hline & & \multirow{3}{*}{1} & & & \\
\hline \multirow{2}{*}{$\begin{array}{l}\text { North } \\
\text { Maluku }\end{array}$} & 0.3799 & & & & \\
\hline & $(4.23)^{* * *}$ & & \multirow{3}{*}{1} & & \\
\hline \multirow{2}{*}{$\begin{array}{l}\text { West } \\
\text { Papua }\end{array}$} & 0.2182 & -0.3131 & & & \\
\hline & $(2.30)^{* *}$ & $(-3.39) * * *$ & & \multirow{3}{*}{1} & \\
\hline \multirow{2}{*}{ Bali } & 0.5981 & 0.4676 & -0.1917 & & \\
\hline & $(10.04)^{* * *}$ & $(5.45)^{* * *}$ & $(-2.01)^{* *}$ & & \\
\hline \multirow{2}{*}{ Aceh } & 0.07477 & 0.5039 & 0.0544 & 0.07775 & \multirow{2}{*}{1} \\
\hline & $(11.59)^{* * *}$ & $(6.01)^{* * *}$ & $(0.56)$ & $(12.73)^{* * *}$ & \\
\hline
\end{tabular}

Note: value at branket denotes $\mathrm{t}_{\text {statistics }}$ value

$\left.* * *) \mathrm{t}_{\text {table }}(0.01 ; 100)=2.364 ; * *\right) \mathrm{t}_{\text {table }}(0.05 ; 100)=1.660$

\section{Conclusion}

In this study, four forms of tuna price behaviors have been analyzed and discussed. These included trends, seasonal variation, variability and instability, and market integration. In term of trend, it was found that tuna prices in all provinces and national level have a positive trend and statistically significant, excluding in West Papua. Implying, the future tuna prices will continue to increase. This is certainly an encouraging finding for the tuna fish business in Indonesia. Especially if this forecast is associated with the results of the study of seasonal behavior of tuna prices which tend not to be affected by seasonality. The wide range of tuna fishing grounds from the eastern and western parts of Indonesia also concluded that the price of tuna in each province in Indonesia is formed independently, does not influence each other, and is influenced by other markets in Indonesia.

This study has revealed how tuna prices behave in 6 main ports of Indonesian tuna producer. The positive trend of tuna prices shows that the tuna fishing business is very promising in the future. However, efforts to maintain price stability are also very important. For this reason, it is important to design and implement policies that are directed at these findings, such as the policy to provide cold storage at production centers to maintain the supply of tuna. No less important is the expansion of the tuna market so that it does not depend on traditional 
markets in addition to downstream processing of tuna products.

This research has also contributed to the study of the price behavior of capture fisheries products which are very difficult to find or rarely done. However, this does not mean that this research is perfect, more research needs to be done related to price behavior, for example price volatility or price rigidity, with other econometric model approaches so that they can contribute more to the expansion of knowledge in this area.

\section{Acknowledgement}

The authors would like to thank Esla, Pesta, Eva, and Ruth at the Agribusiness Study Program for their assistance in collecting data from various sources.

\section{Authors' Contributions}

All authors have contributed to from collecting data, discussion to the final manuscript. The contribution of each author as follow, KS: Idea, Concept, and drafted article; PSA and MN: Discussion and drafted article, NW, RT, and RB for collecting, generating; collected data, and designed the figures. All authors discussed the results and contributed to the final manuscript.

\section{Conflict of Interest}

We declared that no competing interests exist in conjunction with the publication of this article.

\section{Funding Information}

This research is an independent study and was funded by the research team.

\section{References}

Agus, A. (2018). Pengelolaan dan penggunaan sumberdaya kelautan/perikanan studi kasus Kota Ternate, Maluku Utara. Journal of Fisheries and Marine Sciences, 1(2):81-92.

Arias, G. M., O. Chassot, A. R. Melendez, T. M. Poeyo, \& A. Figueroa. (2009). Bi-National Macaw festival to foster the conservation of the Great Green Macaw across borders. V Simposio Mesoamericano de Conservación de Psittaciformes, Belize City, Belize.

Baye, M. R., Morgan, J., \& Scholten, P. (2004). Price dispersion in the small and in the large: Evidence from an internet price comparison site. The Journal of Industrial Economics, 52(4):463-496.
Camara, O. M. (2013). Seasonal price viability and the effective demand for nutrient: Evidence from $\mathrm{Ce}-$ real Market in Mali. African Journal of Food, $\mathrm{Ag}$ riculture, Nutrition and Development, 13(3):76407661.

Chatterjee, S., \& Kapur, D. (2016). Understanding price variation in agricultural commodities in India: MSP, Government Procurement, and Agriculture Markets. NCAER India Policy Forum 2016. Accessed from https://www.ncaer.org/events/ipf2016/IPF-2016-Paper-Chatterjee-Kapur.pdf

Cheng, C. L., Shalabh, \& Garg, G. (2014). Coefficient of determination for multiple measurement error models, Journal of Multivariate Analysis, 126:137-152.

Cuddy, J. D. A., \& Valle, P. A. D. (1978). Measuring the instability of time series data. Oxford Bulletin of Economics and Statistics, 40(1):79-84.

Devi, I. B., Srikala, M., \& Ananda, T. (2016). Price behaviour of chilies in Guntur market of Andhra Pradesh, India. Indian Journal of Agricultural Research, 50(5):471-474.

FAO (Food and Agriculture Organization). (2018). Fishery and aquaculture statistics. Rome: FAO.

Goyal, S. K. (2008). Growth and instability on revised export marketing of onion. Indian Journal of Agricultural Marketing, 22(3):11-24.

Hassanzoy, N., Ito, S., Isoda, H., \& Amekawa, Y. (2016). The effects of swings in global wheat prices on the domestic markets in Afghanistan. International Journal of Food and Agricultural Economics, $4(4): 45-58$.

Hoffmann, R. (1998). Statistics for economists. Sao Paulo: Pioneer. $430 \mathrm{p}$.

Kaminski J., Christiaensen L., \& Gilbert, C. L. (2016). Seasonality in local food markets and consumption: Evidence from Tanzania. Policy Research Working Paper, 7520.

Kekenusa, J. S., Watung, V. N. R., \& Hatidja, D. (2012). Analisis penentuan musim penangkapan ikan cakalang (Katsuwonus pelamis) di Perairan Manado Sulawesi Utara. Jurnal Ilmiah Sains, 12(2):112199.

Khajuria, Vinod, Sharma, O. P., \& Jain, H. K. (2008). A study on fish production, marketing and price behavior in Udaipur (Rajasthan). Indian Journal of Agricultural Marketing, 22(2):152-169. 
KKP (Kementrian Kelautan dan Perikanan). (2014). Siaran pers: Potensi tuna Indonesia tertinggi di dunia. Retrieved on June 20, 2021 from http://kkp. go.id/indexphp/arsip/c/10421/PotensiTuna-Indonesia-Tertinggi-DiDunia/?category_id.

KKP (Kementrian Kelautan dan Perikanan). (2021). Produksi perikanan. Retrieved on June 20, 2021 from https://statistik.kkp.go.id/home.php?m=total\&i=2.

Kumar, V., Sharma, H. R., \& Sharma, R. K. (2006). Market arrivals and the price behavior of potato: A study of four metropolitan markets. Indian Journal of Agricultural Marketing, 20(1):78-89.

Kumar, P., \& Sharma, A. (2006). Price variability and its determinants: An analysis of major foodgrains in India. Indian Economic Review, 41(2):149-172.

Kurniawan, D. N., Ghofar, A., Saputra, A.W., \& Setyadji, B. (2016). Tingkat eksploitasi ikan tuna sirip biru selatan (Thunnus maccoyii) di Samudera Hindia berdasarkan hasil tangkapan yang didaratkan di Pelabuhan Benoa, Bali. Diponegoro Journal of Maquares, 5(4):345-352.

Lach, S. (2002). Existence and persistence of price dispersion: An empirical analysis. The Review of Economics and Statistics, 84(3):433-444.

Levy, D. (2007) Price rigidity and flexibility: Recent theoretical developments. Managerial \& Decision Economics, 28(6):523-530.

Makbul, Y., Ratnaningtyas, S., \& Soniaty, S. (2019). Integration rice price and farmers welfare with error correction model analysis. Archives of Business Research, 7(9):221-228.

Maygirtasari, T., Yulianto, E., \& Mawardi, M. K. (2015). Faktor-faktor yang mempengaruhi volume ekspor crude palm oil (CPO) Indonesia. Jurnal Administrasi Bisnis, 25(2):1-8.

Miftahuljanah, Sukiyono, K., \& Asriani, P. S. (2020). Volatilitas dan transmisi harga cabai merah keriting pada pasar vertikal di Provinsi Bengkulu. Jurnal Agro Ekonomi, 38(1):29-39.

Mustapha, M. \& Richard, J. C. (2013). Causes, magnitude and consequences of price variability in agricultural commodity market: An African perspective journal. Murdoch University: The Economic Society of Australia.

Nakelse, T., Dalton, T. J., Hendricks, N. P., \& Hodjo, M. (2018). Are smallholder farmers better or worse off from an increase in the international price of cereals? Food Policy, 79(C):213-223.

Nasution, M. H., Anwar, S., Fitri, A., \& Zohra, A. F. (2019). Forecasting the amount of tuna/madidihang (Yellowfin tuna) landed in PPS Kutaraja Banda Aceh City with the triple exponential smoothing method. Jurnal Ilmu Perikanan, 10(1):8-14.

Neupane H. S., \& Calkins, P. (2013). An empirical analysis of price behavior of natural rubber latex: A case of central rubber market Hat Yai, Songkhla, Thailand. In V. N. Huynh, V. Kreinovich, S. Sriboonchitta, K. Suriya (Ed.), Uncertainty analysis in econometrics with applications. advances in intelligent systems and computing. (pp.185-201). Berlin: Springer.

Nidausoleha, O. (2007). Analisis perilaku harga dan keterpaduan pasar komoditas bawang merah di Jawa. Thesis. Yogyakarta: Universitas Gadjah Mada (unpublish).

Pandit, Arun, P. Samal., \& Jyoti R. Mishra. (2012). An analysis of price behavior of rice in Eastern Indian markets. Indian Journal of Agricultural Marketing, 26(2):102-109.

Purnomo, B. H. (2012). Peranan perikanan tangkap berkelanjutan untuk menunjang ketahanan pangan di Indonesia. Paper presented at Seminar Nasional Kedaualatn Pangan dan Energi, Fakultas Pertanian, Universitas Trunojoyo, Indonesia.

Rana, R. K., Pandit, A., Pandey, N. K., \& Kumar, N. R. (2003). Lack of integration of major potato market in India. Journal of the Indian Potato Association. 30(1/2):205-206.

Rizal, A., Iskandar, Herawati, H., \& Dewanti, L. P. (2018). Potret dan review: Strategi pembangunan perikanan dan kelautan. Bandung: Unpad Press.

Sanger, C. L. M., Jusuf, A., \& Andaki, J. A. (2019). Analisis orientasi kewirausahaan nelayan tangkap skala kecil dengan alat tangkap "JUBI" di Kelurahan Batulubang Kecamatan Lembeh Selatan Kota Bitung. Akulturasi: Jurnal Ilmiah Agrobisnis Perikanan, 7(1):1095-1101

Sharma, H., \& Burark, S. S. (2015). A study of seasonal price behaviour and market concentration of maize in Rajasthan. International Research Journal of Agricultural Economics and Statistics, 6(2):282286.

Sidik, F., Nurani, T. W., Wisudo, S. H. (2013). Mutu dan 
perdagangan ikan tuna hasil tangkapan longline yang didaratkan di PPS Nizam Zachman Jakarta. Buletin PSP, 21(2):157-166.

Singh, D. K., Pynbianglang, K., \& Pandey, N. K. (2017). Market arrival and price behaviour of potato in Agra District of Uttar Pradesh. Economic Affairs, 62(2):341-345.

Singh, S., \& Ru, C. G. (2019). Price rigidity, market competition, and product differentiation. Economic Research-Ekonomska Istraživanja, 32(1):29412958.

Singvejsakul, J., Yaovarate, C., \& Limnirankul, B. (2021). Modeling the price volatility of cassava chips in Thailand: Evidence from Bayesian GARCH-X Estimates. Economies, 9(3):132.

Sukiyono, K. \& Kaban, H. I. (2007). Perilaku harga dan pemasaran ikan hasil tangkapan di Propinsi Bengkulu. Jurnal AGRISEP Kajian Masalah Sosial Ekonomi Pertanian dan Agribisnis, 6(1):116131.

Sukiyono, K., Cahyadinata, I., Purwoko, A., Widiono, S., Sumartono, E., Arianti, N. N. \& Mulyasari, G. (2017). Assessing smallholder household vulnerability to price volatility of palm fresh fruit Bunch in Bengkulu Province. International Journal of Applied Business and Economic Research, 15:1-15.
Thumar, V. M., Gajipara, H. M., \& Khunt, K. A. (2006). Growth and instability in production and export marketing of garlic. Indian Journal of Agricultural Marketing, 20(2):25-33.

TMI (Tridge Market Intelegent). (2021). Global export tuna export overview of top 10 countries. Retrieved on June 20, 2021 from https://www.tridge. com/intelligences/atlantic-bluefin-tuna/export.

Triarso, I. (2012). Potensi dan peluang pengembangan usaha perikanan tangkap di Pantura Jawa Tengah. Jurnal Saintek Perikanan, 8(1):65-73.

Uktolseja, J. C. B., Gafa, B., \& Bahar, S. (1991). Potensi dan penyebaran sumberdaya ikan tuna dan cakalang. In P. Martosubroto, N. Naamin, B.B.A Malik (Ed.), Potensi dan penyebaran sumberdaya ikan laut di Perairan Indonesia. (p. 29-43). Jakarta: Direktorat Jenderal Perikanan. Pusat Penelitian dan Pengembangan Perikanan. Pusat Penelitian dan Pengembangan Oseanologi.

Widayanti, S., Kiptiyah, S. M., \& Semaoen, M. I. (2009). Analisis ekspor kopi Indonesia. Wacana, 12(1):192-203.

Yusuf, R., Arthatiani, F. Y., \& Maharani, H. (2017). Peluang pasar ekspor tuna Indonesia: Suatu pendekatan analisis Bayesian. Jurnal Kebijakan Sosial Ekonomi Kelautan dan Perikanan, 7(1):39-50. 